\title{
接合部のせん断変形を考慮した RC骨組の非線形挙動解析 \\ NON-LINEAR BEHAVIOR ANALYSIS OF RC FRAME STRUCTURE CONSIDERING SHEAR DEFORMATION OF JOINT
}

\author{
齊藤隆典*, 越川武晃 ${ }^{* *}$, 上田正生 ${ }^{* *}$, 菊地 優**** \\ Takasuke SAITO, Takeaki KOSHIKAWA, Masaiki UEDA \\ and Masaru KIKUCHI
}

\begin{abstract}
Two dimensional non-linear analysis of reinforced-concrete frame structure considering shear behavior of joint panel is presented in the paper. Inelastic joint shear action under reversed-cyclic loadings is complicated: interaction between shear deformation of joint panel and bond failure of longitudinal reinforcements embedded in the joint. The purpose of the research is to propose a simple beam-column joint model to predict such a behavior of a joint panel. A finite element formulation of fiber beam/column elements, new joint element considering shear deformation and material model defined in analysis are presented. Simulation analyses for three different type beam-column joint specimens are conducted to confirm the validity of the proposed method.
\end{abstract}

Keywords : Beam-Column Joint, Shear Deformation, Bond-Slip, RC Frame, Finite Element Method 柱梁接合部, せん断変形, 付着すべり, RC 骨組, 有限要素法

1.はじめに

鉄筋コンクリート（RC）骨組の耐震設計を行う場合，梁曲げ降伏 型の破壊形式を目標とすることが一般的であり，柱梁接合部に過度 の塑性変形を生じさせないことが望ましい 1)。しかしながら， RC 骨組が地震力を受ける場合，接合部パネル部分のせん断ひび割れの 発生や接合部内部主筋の付着劣化を回避することは現実的に困難で あり，既往の RC 骨組を対象とした実験結果や地震被害報告等では， 接合部が損傷し，その力学的性能が低下する危険性が指摘されてい る。このような状況における $\mathrm{RC}$ 骨組の履歴特性はエネルギ一吸収 能の乏しい，いわゆる逆 $\mathrm{S}$ 字型の履歴形状となることが知られてい るが，これがより顕著となるような場合には建物全体の応答に大き な影響を及ぼしかねない。従って， RC 骨組の性能を評価する上で， 接合部の力学的挙動を考慮することが重要である。

RC 骨組の接合部は一般的に梁・柱主筋が内部に通し配筋され， その付着状態や接合部周りの応力状態が骨組の変形とともに刻々と 変化する等, 力学的に多様な要因を含む部材であり，その変形挙動 は極めて複雑なものである。このような部材の力学特性を解析にお いて表現する場合には，その特致を捉えたより簡便なモデル化を行 うことが理想的である。 RC 骨組を対象として接合部の解析モデル を提案している既往の研究について概観してみると，接合部のせん 断変形および鉄筋の付着すべりを考慮した解析法としては，坂田等 の研究 ${ }^{2)}$, Lowes 等の研究 3$)$ を挙げることができる。坂田等はせん
断変形する接合部内部の主筋のすべり現象についても評価し得る解 析法を提案している。しかし，この解析法では繰り返し荷重を受け る接合部の変形挙動を評価する上で，特に影響が大きいと考えられ る接合部パネルのせん断応力ーせん断歪関係と鉄筋の付着応力一す ベり変位関係の各履歷則には比較的簡易なモデル化が施されており, より詳細な非線形挙動を考慮しているとは言い難い。また, Lowes 等は接合部パネルとこれに接続する各種一軸ばねから構成した接合 部要素を提案しているが，このモデルにおける鉄筋の変形は，接合 部パネルの四隅に接続する 8 つ一一軸ばねを用いて表現しているた め, 接合部内部の鉄筋のすべり現象については直接的に取り扱える 手法ではない。

著者等は既に付着すべりを考慮した RC 梁・柱要素と剛体を仮定 した RC 接合部要素を併用した, 梁曲げ降伏型 RC 骨組を対象とす

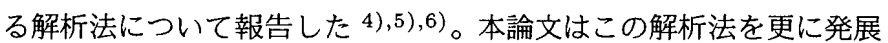
させ，新たにせん断変形を考虑可能な RC 接合部要素を導入した， $\mathrm{RC}$ 骨組の材料非線形解析法について報告するものである。本論文 ではまず，本解析法の基本である付着すべりを考慮した RC 梁・柱 要素の有限要素法への定式化について概述し, 次いで, 新たに提案 するせん断変形を考慮可能な $\mathrm{RC}$ 接合部要素とその全体解析への適 用法について記述する。また，新たな接合部要素に適用する接合部 パネルのせん断応力ーせん断歪関係を中心に解析に用いる各材料モ デルについて示し, 更に, 数値計算例として既往の実験結果との比

\footnotetext{
* 北海道大学大学院工学研究科 大学院生 $\cdot$ 修士 (工学)

** 北海道大学大学院工学研究科 助教・博士 (工学

*** 北海道大学大学院工学研究科 教授・博士 (工学

$* * * *$ 北海道大学大学院工学研究科准教授・博士 (工学
}

Graduate Student, Graduate School of Engineering, Hokkaido University, M. Eng. Assistant Prof., Graduate School of Engineering, Hokkaido University, Dr. Eng. Prof., Graduate School of Engineering, Hokkaido University, Dr. Eng. Assoc. Prof., Graduate School of Engineering, Hokkaido University, Dr. Eng. 
較，考察を行うことで，本解析法の妥当性の検証と接合部のせん断 変形の考虑が RC 骨組の性能, 主筋のすべり量の評価に及ぼす影響 について検討する。

2. RC 梁・柱要素の有限要素法への定式化

\section{1 基本仮定事項}

ここでは，本解析法の基本となる鉄筋の付着すべりを考慮した RC 梁・柱要素の有限要素法への定式化について概述する。定式化にあ たって設定した基本仮定事項は以下に示す通りである。

(1)RC 梁・柱要素には曲げと軸力が作用し, コンクリート断面には

鉄筋のすべりに拘らず平面保持が成立すると仮定する。また，こ の仮定に基づく微小変形理論を適用する。

(2)要素断面を図 1 に示すような部材丈方向で $n$ 層に仮想分割して取 り扱うファイバーモデルで表示する。

(3)鉄筋とコンクリートの間には，材軸方向の付着すべりが生じ得る ものとし，任意位置における鉄筋層のすべり変位は，平面が保持 されるその位置のコンクリート断面からの相対変位で表示する。 (4)要素内の各コンクリート層, 各鉄筋層の材料性状は, 各層の中央 位置の值で評価し，個々の層内では一定の性状を有する。

2.2 変位場および歪増分・応力増分

(1) 変位場

基本仮定に基づいて， $\mathrm{RC}$ 梁・柱要素の定式化のために設定した 変位場は, 図 1 に示すように, 要素の軸方向変位 $u$, 鉛直方向変位 $w$ ，および各要素断面内に配筋されている鉄筋層 ( $m$ 層) のすべり変 位 $s_{1}, s_{2}, \cdots, s_{i}, \cdots, s_{m}$ の計 $(2+m)$ 個の変位である。材料非線形 解析にあたり，これらの変位は増分形式で表示される。

(2) コンクリート層の歪増分と応力増分

基準軸から $z_{i}$ の距離にある任意のコンクリート層 $i$ の歪增分 $\Delta \varepsilon_{c_{i}}$, 応力増分 $\Delta \sigma_{c_{i}}$ は次式で表される。

$$
\begin{aligned}
& \Delta \varepsilon_{c_{i}}=\Delta \varepsilon_{o}+z_{i} \Delta \phi=\frac{d \Delta u}{d x}-z_{i} \frac{d^{2} \Delta w}{d x^{2}} \\
& \Delta \sigma_{c_{i}}=E_{c_{i}} \Delta \varepsilon_{c_{i}}
\end{aligned}
$$

但し, $\Delta \varepsilon_{0}$ : 要素基準軸上の軸方向歪増分, $\Delta \phi$ : 要素の曲率増 分, $E_{c_{i}}$ : コンクリート層 $i$ の接線剛性

\section{(3) 鉄筋層の歪増分と応力増分}

断面内の $m$ 層の鉄筋層のうち, 基準軸から $h_{s_{i}}$ の距離にある任 意の鉄筋層 $i$ の歪増分 $\Delta \varepsilon_{s_{i}}$, 応力増分 $\Delta \sigma_{s_{i}}$ は次式で表される。

$$
\begin{aligned}
& \Delta \varepsilon_{s_{i}}=\Delta \varepsilon_{o}+h_{s_{i}} \Delta \phi+\Delta \varepsilon_{s s_{i}}=\frac{d \Delta u}{d x}-h_{s_{i}} \frac{d^{2} \Delta w}{d x^{2}}+\frac{d \Delta s_{i}}{d x} \\
& \Delta \sigma_{s_{i}}=E_{s_{i}} \Delta \varepsilon_{s_{i}}
\end{aligned}
$$

但し, $\Delta \varepsilon_{s s_{i}}$ : 鉄筋層 $i$ のすべり率の増分（すべり変位增分の微 分量）， $E_{s_{i}}$ : 鉄筋層 $i$ の接線剛性

(4) 鉄筋層の付着応力増分とすべり変位増分

任意の鉄筋層 $i$ の付着応力増分 $\Delta \tau_{b_{i}}$ とすべり変位増分 $\Delta s_{i}$ との 間には，基本仮定より次の関係が成立する。

$$
\Delta \tau_{b_{i}}=K_{b_{i}} \Delta s_{i}
$$

但し, $K_{b_{i}}$ : 鉄筋層 $i$ の接線付着剛性

2.3 全ポテンシャル・エネルギー汎関数

鉄筋の付着すべりを考慮した RC 梁・柱要素のための増分型全ポ テンシャル・エネルギー沉関数 $\Delta \Pi$ は, 次式で表すことができる。

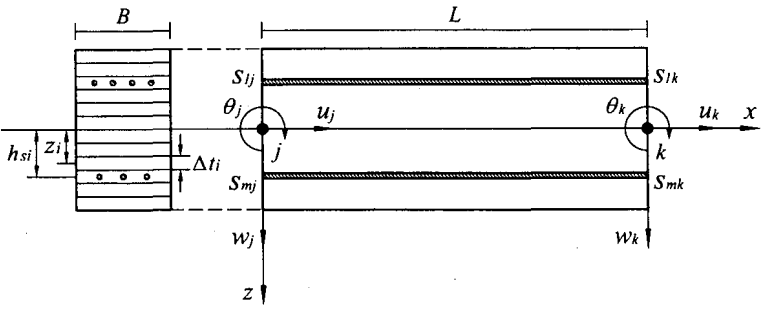

図 $1 \quad \mathrm{RC}$ 梁・柱要素

$\Delta \Pi=\left(\Delta U_{c n}+\Delta U_{s t}+\Delta U_{b s}\right)-\Delta V$

但し, $\Delta U_{c n}$ : コンクリートに係る内部エネルギ一増分, $\Delta U_{s t}$ : 鉄筋に係る内部エネルギ一増分， $\Delta U_{b s}$ : 付着すべりに係 る内部エネルギー増分, $\Delta V$ : 外力によるエネルギ一增分 前節の関係を用いて (6) 式を展開し, 各変位增分について整理す ると， $\Delta \Pi$ は，最終的に次のように表すことができる。

$$
\begin{aligned}
& \Delta \Pi=\frac{1}{2} \int_{0}^{L}\left[\left\{\sum_{i=1}^{n} B_{i} \Delta t_{i} E_{c_{i}}+\sum_{i=1}^{m} A_{s i}^{*} E_{s_{i}}\right\}\left(\frac{d \Delta u}{d x}\right)^{2}\right. \\
& -2\left\{\sum_{i=1}^{n} B_{i} \Delta t_{i} E_{c_{i}} z_{i}+\sum_{i=1}^{m} A_{s_{i}}^{*} E_{s_{i}} h_{s_{i}}\right\}\left(\frac{d \Delta u}{d x}\right)\left(\frac{d^{2} \Delta w}{d x^{2}}\right) \\
& +2 \sum_{i=1}^{m} A_{s_{i}} E_{s_{i}}\left(\frac{d \Delta u}{d x}\right)\left(\frac{d \Delta s_{i}}{d x}\right) \\
& +\left\{\sum_{i=1}^{n} B_{i} \Delta t_{i} E_{c_{i}} z_{i}^{2}+\sum_{i=1}^{m} A_{s_{i}}^{*} E_{s_{i}} h_{s_{i}}^{2}\right\}\left(\frac{d^{2} \Delta w}{d x^{2}}\right)^{2} \\
& -2 \sum_{i=1}^{m} A_{s_{i}} E_{s_{i}} h_{s_{i}}\left(\frac{d^{2} \Delta w}{d x^{2}}\right)\left(\frac{d \Delta s_{i}}{d x}\right) \\
& \left.+\sum_{i=1}^{m} A_{s_{i}} E_{s_{i}}\left(\frac{d \Delta s_{i}}{d x}\right)^{2}+\sum_{i=1}^{m} A_{b s_{i}} K_{b_{i}} \Delta s_{i}{ }^{2}\right] d x \\
& -\int_{0}^{L}\left\{\Delta P_{u}\left(\frac{d \Delta u}{d x}\right)+\Delta q_{z} \Delta w+\sum_{i=1}^{m} \Delta P_{s_{i}}\left(\frac{d \Delta s_{i}}{d x}\right)\right\} d x
\end{aligned}
$$

但し, $L$ : 要素長さ, $A_{s_{i}}$ : 鉄筋層 $i$ の断面積, $A_{b s_{i}}$ : 鉄筋層 $i$ の単位長さあたりの付着表面積, $A_{s_{i}}^{*}$ : 鉄筋層 $i$ の換算断 面積で $A_{s_{i}}^{*}=A_{s_{i}}\left(1-\frac{E_{c_{i}}}{E_{s_{i}}}\right), \Delta P_{u}$ : 材軸方向荷重増分, $\Delta q_{z}$ : 鉛直方向分布荷重増分, $\Delta P_{s_{i}}$ : 鉄筋層 $i$ の荷重増分

\section{$2.4 \mathrm{RC}$ 梁・柱要素の有限要素方程式}

要素の各変位増分 $\Delta u, \Delta w, \Delta s_{i}$ （但し, $i=1 \sim m$ ）の要素内に おける変位関数をそれぞれ 1 次, 3 次, 1 次と設定すると, 図 1 の要 素両節点 $j, k$ における各節点変位ベクトル増分 $\{\delta u\},\{\delta w\},\left\{\delta s_{i}\right\}$ は各変位増分を用いて次のように表される。

$$
\begin{aligned}
& \{\delta u\}=\left\{\begin{array}{ll}
\Delta u_{j} & \Delta u_{k}
\end{array}\right\}^{T} \\
& \{\delta w\}=\left\{\begin{array}{llll}
\Delta w_{j} & \Delta \theta_{j} & \Delta w_{k} & \Delta \theta_{k}
\end{array}\right\}^{T} \\
& \left\{\delta s_{i}\right\}=\left\{\begin{array}{ll}
\Delta s_{i j} & \Delta s_{i k}
\end{array}\right\}^{T}
\end{aligned}
$$

但し; $\theta:$ 各節点の回転変位を表す項で, $\theta=\frac{d w}{d x}$

(7) 式を (8) （10) 式の各節点変位ベクトル増分に関してそれぞれ変 分をとり整理すると, 最終的に次式の有限要素方程式を得る。

$$
\left[\begin{array}{lll}
K_{u u} & K_{u w} & K_{u s} \\
K_{u w}^{T} & K_{w w} & K_{w s} \\
K_{u s}^{T} & K_{w s}^{T} & K_{s s}
\end{array}\right]\left\{\begin{array}{c}
\delta u \\
\delta w \\
\delta s
\end{array}\right\}=\left\{\begin{array}{l}
\delta P_{u} \\
\delta P_{w} \\
\delta P_{s}
\end{array}\right\}
$$

但し, $[K]$ : 各変位増分と対応した剛性マトリクス, $\{\delta s\}:$ すべ ての鉄筋に関する節点すべり変位ベクトル増分, $\{\delta P\}$ : 各 変位增分と対応した節点荷重ベクトル増分 


\section{3. せん断変形を考慮した RC 接合部要素}

著者等は文献 4) 6) において, 柱梁接合部内主筋の付着すべり を考慮した RC 接合部要素を提案している。図 2 はそ.の RC 接合部 要素の基本構成について示したものである。この要素は，前章にお いて展開した鉄筋の付着すべりを考慮した $\mathrm{RC}$ 梁・柱要素を 2 要素 組み合わせて構成したモデルで, 各節点の自由度数は, 骨組解析に あたり接合部要素に接続される梁・柱要素と同数である。そのため, 鉄筋のすべり変位を含めたすべての変位の連続性は保持されており, 接合部を介して梁・柱部材に通し配筋される鉄筋の付着すべり現象 を表現可能な要素である。

本論文では，この RC 接合部要素を基にして，更に次の 2 点を考 慮し得るように拡張を行う。

(1)接合部パネルのせん断変形

(2)接合部内部の鉄筋の付着すべり分布

本章では，以上の点を考慮した RC 接合部要素を構築し，最終的に 骨組解析に用いる RC 接合部要素の有限要素方程式を導出する。次 節より各設定手法について分けて詳述する。

\section{1 接合部パネルのせん断変形の考慮}

$\mathrm{RC}$ 接合部要素を構築するにあたりまず，接合部パネルの変形に せん断変形を許容するため, 接合部要素の各節点の変位間に拘束条 件を設定する。更に，この条件を解析法に取り入れるための変位の 変換を行い, 変換後の接合部要素の有限要素方程式を導く。以下に おいて，具体的な設定手法について記述する。

(1) 接合部要素の節点変位の変換

図 3 にせん断変形を考慮した接合部要素の変位場を示す。図中に 示す変位の添え字は各節点を表しており，この図では簡略化のため 鉄筋のすべり変位については省略している。ここで, 4 つの節点 $l$, $r, b, t$ で構成される接合部パネルが一様にせん断変形するものと 仮定すると, この要素のせん断変形は, 梁軸方向 ( $x$ 軸方向) および 柱軸方向 ( $z$ 軸方向) のせん断変形の重ね合わせで表すことができ る。即ち, 接合部要素の任意位置でのせん断変位増分の水平成分を $\Delta u_{j c}$, 鉛直成分を $\Delta w_{j c}$ とし, 要素内における変位関数をそれぞれ 1 次と設定すると，接合部のせん断歪 $\Delta \gamma$ は次のように表現できる。

$$
\Delta \gamma=\frac{d \Delta u_{j c}}{d z}+\frac{d \Delta w_{j c}}{d x}=\frac{\Delta u_{b}-\Delta u_{t}}{H}+\frac{\Delta w_{r}-\Delta w_{l}}{L}
$$

但し, $H$ : 接合部要素の高さ, $L$ : 接合部要素の幅

一方，この関係を接合部パネルの变形として解析法に組み込むた め, (12) 式中の 4 つの変位以外の節点変位に拘束条件を設定する。 図 4 は要素が一様にせん断変形する場合の, 変形後の各節点変位増 分を示している。この図の幾何学的関係より以下の式を得る。

$$
\begin{aligned}
& \Delta u_{l}-\frac{\Delta u_{b}}{2}-\frac{\Delta u_{t}}{2}=\Delta u_{l}^{\prime}=0 \\
& \Delta u_{r}-\frac{\Delta u_{b}}{2}-\frac{\Delta u_{t}}{2}=\Delta u_{r}^{\prime}=0 \\
& \Delta \theta_{l}+\frac{\Delta u_{b}}{H}-\frac{\Delta u_{t}}{H}=\Delta \theta_{l}^{\prime}=0 \\
& \Delta \theta_{r}+\frac{\Delta u_{b}}{H}-\frac{\Delta u_{t}}{H}=\Delta \theta_{r}^{\prime}=0 \\
& \Delta w_{b}-\frac{\Delta w_{l}}{2}-\frac{\Delta w_{r}}{2}=\Delta w_{b}^{\prime}=0 \\
& \Delta w_{t}-\frac{\Delta w_{l}}{2}-\frac{\Delta w_{r}}{2}=\Delta w_{t}^{\prime}=0 \\
& \Delta \theta_{b}+\frac{\Delta w_{l}}{L}-\frac{\Delta w_{r}}{L}=\Delta \theta_{b}^{\prime}=0
\end{aligned}
$$

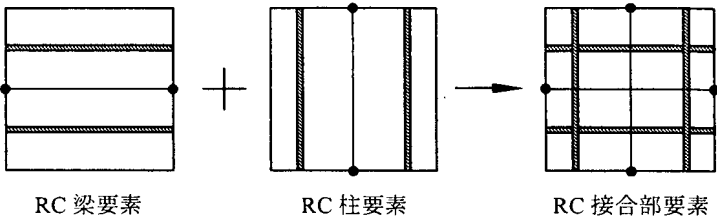

図 $2 R C$ 接合部要素の構成
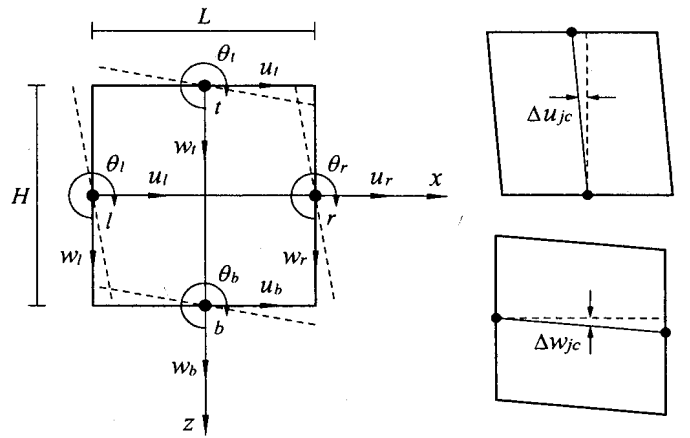

図 3 接合部要素の変位場

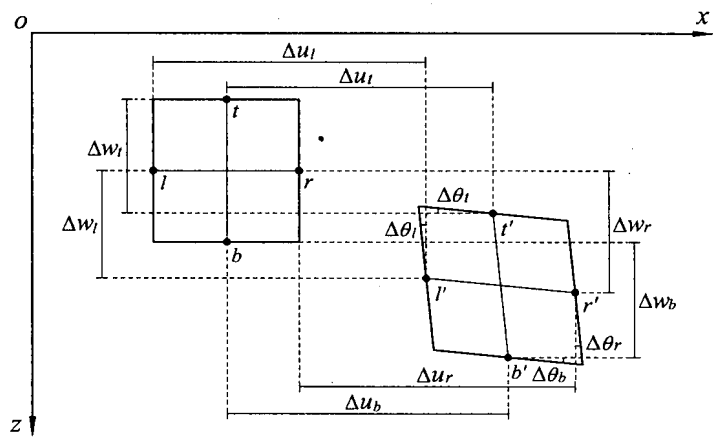

図 4 接合部要素の各節点変位增分

$\Delta \theta_{t}+\frac{\Delta w_{l}}{L}-\frac{\Delta w_{r}}{L}=\Delta \theta_{t}^{\prime}=0$

(13) （20) 式の関係から次に示す変位の変換式が得られる。

$\left\{\begin{array}{c}\Delta_{l}^{\prime} \\ \Delta_{r}^{\prime} \\ \Delta_{b}^{\prime} \\ \Delta_{t}^{\prime}\end{array}\right\}=\left[\begin{array}{cccc}I & O & T_{l} & T_{r} \\ O & I & T_{l} & T_{r} \\ T_{b} & T_{t} & I & O \\ T_{b} & T_{t} & O & I\end{array}\right]\left\{\begin{array}{c}\Delta_{l} \\ \Delta_{r} \\ \Delta_{b} \\ \Delta_{t}\end{array}\right\}$

但し, $[I]:$ 単位行列, $[O]:$ 零行列 ここに,

$\left\{\Delta_{l}\right\}=\left\{\begin{array}{llll}\Delta u_{l} & \Delta w_{l} & \Delta \theta_{l} & \Delta s_{i l}\end{array}\right\}^{T},\left\{\Delta_{r}\right\}=\left\{\begin{array}{lll}\Delta u_{r} \Delta w_{r} & \Delta \theta_{r} \Delta s_{i r}\end{array}\right\}^{T}$

$\left\{\Delta_{b}\right\}=\left\{\begin{array}{lll}\Delta u_{b} \Delta w_{b} \quad \Delta \theta_{b} \Delta s_{i b}\end{array}\right\}^{T},\left\{\Delta_{t}\right\}=\left\{\begin{array}{llll}\Delta u_{t} & \Delta w_{t} \Delta \theta_{t} \Delta s_{i t}\end{array}\right\}^{T}$

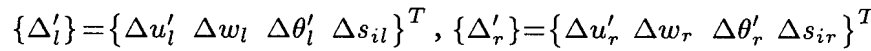

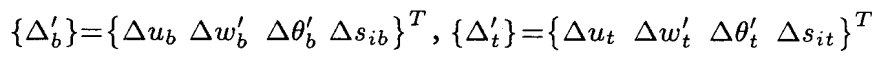

$\left[T_{l}\right]=\left[\begin{array}{cccc}-\frac{1}{2} & 0 & 0 & 0 \\ 0 & 0 & 0 & 0 \\ \frac{1}{H} & 0 & 0 & 0 \\ 0 & 0 & 0 & 0\end{array}\right],\left[T_{r}\right]=\left[\begin{array}{cccc}-\frac{1}{2} & 0 & 0 & 0 \\ 0 & 0 & 0 & 0 \\ -\frac{1}{H} & 0 & 0 & 0 \\ 0 & 0 & 0 & 0\end{array}\right]$

$\left[T_{b}\right]=\left[\begin{array}{rrrr}0 & 0 & 0 & 0 \\ 0 & -\frac{1}{2} & 0 & 0 \\ 0 & \frac{1}{L} & 0 & 0 \\ 0 & 0 & 0 & 0\end{array}\right],\left[T_{t}\right]=\left[\begin{array}{rrrr}0 & 0 & 0 & 0 \\ 0 & -\frac{1}{2} & 0 & 0 \\ 0 & -\frac{1}{L} & 0 & 0 \\ 0 & 0 & 0 & 0\end{array}\right]$

(21) 式を簡略化して再表示したものを次式で表す。 


$$
\left\{\delta_{j p}^{\prime}\right\}=\left[T_{j p}\right]\left\{\delta_{j p}\right\}
$$

(22) 式の $\left\{\delta_{j p}^{\prime}\right\}$ は変換後の接合部要素の節点変位ベクトル増分を表 しており， $\left[T_{j p}\right]$ は接合部パネルのせん断変形を表現するために接 合部要素に設定した変位変換マトリクスである。

(2) 接合部要素の有限要素方程式

せん断変形を考虑した接合部要素のための增分型全ポテンシャル． エネルギー汎関数 $\Delta \Pi_{j c}$ は (12) 式の $\Delta \gamma$ を用いて，次式で表せる。

$$
\Delta \Pi_{j c}=\frac{1}{2} \int_{0}^{H} \int_{0}^{L} G B(\Delta \gamma)^{2} d x d z-\int_{0}^{H} \int_{0}^{L} G B \Delta \gamma d x d z
$$

但し, $G$ : 接合部パネルのせん断応力ーせん断歪関係における接 線剛性， $B$ : 接合部要素の奥行

この式を展開し，整理することで接合部要素の有限要素方程式を導 くことができ，(12) 式中の 4 つの変位増分に対応した剛性マトリク スおよび節点荷重ベクトル増分を得る。

ここで得た值と $(22)$ 式の変換式から変位変換後の接合部要素の有 限要素方程式を導くが, この変換では接合部要素に接続される 4 つ の梁・柱要素の変位にも影響を及ぼすため，これらを含めた上で変 換を行う必要がある。即ち，接合部要素とこれに接続する梁・柱要 素を含めた節点変位ベクトル増分を $\left\{\delta_{j o i}\right\}$ ，変換マトリクス $\left[T_{j p}\right]$ を梁・柱要素の変位を含めた $(24+8 m)$ 次のマトリクスに拡幅した 上で, $l, r, b, t$ 以外の節点と対応する部分の対角要素を単位行列 としたものを $\left[T_{j o i}\right]$ とすると, (22) 式と同様の次式を得る。

$\left\{\delta_{j o i}^{\prime}\right\}=\left[T_{j o i}\right]\left\{\delta_{j o i}\right\}$

また，節点変位べクトル増分が $\left\{\delta_{j o i}\right\}$ である有限要素方程式に，(23) 式より得た剛性マトリクス，節点荷重ベクトル増分を (12) 式中の 4 つの変位増分と対応した部分に構成した上で，(24) 式とを用いて変 位の変換を行うと, 変換後の接合部要素の有限要素方程式は次式の ように表すことができる。

$$
\left(\left[T_{j o i}^{-1}\right]\right)^{T}\left[K_{j o i}\right]\left[T_{j o i}^{-1}\right]\left\{\delta_{j o i}^{\prime}\right\}=\left(\left[T_{j o i}^{-1}\right]\right)^{T}\left\{\delta P_{j o i}\right\}
$$

但し, $\left[K_{j o i}\right]$ : 接合部要素と接続する梁・柱要素を含めた剛性マ トリクス, $\left\{\delta P_{j o i}\right\}$ : 接合部要素と接続する梁・柱要素を 含めた節点荷重ベクトル増分

この式の $\left\{\delta_{j o i}^{\prime}\right\}$ のうち，(13) (20) 式と対応した変位增分の值が 0 となる拘束条件を導入することで，(12) 式の関係を満足した接合部 要素の変形状態を得ることが可能となる。

\section{2 接合部内部の鉄筋の付着すべり分布の考慮}

ここでは，せん断変形を許容した接合部内部の鉄筋の付着すべり 分布を表現するために, 前節の接合部要素に内部節点を付加し, こ れを含めた有限要素方程式を導いた上で，その縮約を行う。この方 法は文献 6) と基本的に同様であるが，本論文ではせん断変形を許容 した接合部要素にこれを適用するため，変位の変換手法が異なって いる。以下から各設定方法について記述する。

(1) 接合部要素内部に付加した節点変位の変換

図 5 は，接合部要素の節点 $l, r$ 間に $q$ 個の内部節点を付加し，要 素がせん断変形する場合を示したもので，図中の節点 $l, r$ は図 4 中 の各節点と対応する。ここでは簡便のため, 梁軸方向の設定につい て記述するが，柱軸方向についても同様の設定を行うものとする。 前節より，接合部パネルは一様にせん断変形すると仮定しているの で，内部節点の変位についてもこの仮定を満足するように，鉄筋の

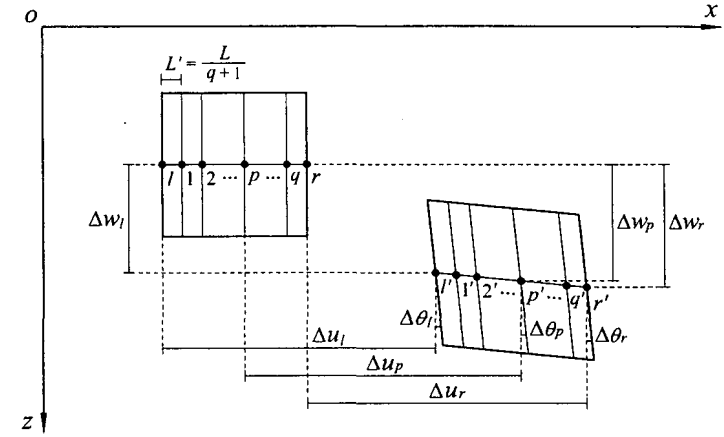

図 5 内部節点を付加した接合部要素の各節点変位増分

すべり変位を除く変位に拘束条件を設定する。図 5 の幾何学的関係 より，節点 $l$ から $p$ 番目の任意の内部節点について以下の式を得る。

$$
\begin{aligned}
& \Delta u_{p}-\Delta u_{l}=\Delta u_{p}^{\prime}=0 \\
& \Delta w_{p}-\left(\frac{q+1-p}{q+1}\right) \Delta w_{l}-\left(\frac{p}{q+1}\right) \Delta w_{r}=\Delta w_{p}^{\prime}=0 \\
& \Delta \theta_{p}-\Delta \theta_{l}=\Delta \theta_{p}^{\prime}=0
\end{aligned}
$$

これらの関係式から以下に示す変位の変換式が得られる。

$$
\left\{\begin{array}{c}
\Delta_{l} \\
\Delta_{p}^{\prime} \\
\Delta_{r}
\end{array}\right\}=\left[\begin{array}{ccc}
I & O & O \\
T_{p_{l}} & I & T_{p_{r}} \\
O & O & I
\end{array}\right]\left\{\begin{array}{c}
\Delta_{l} \\
\Delta_{p} \\
\Delta_{r}
\end{array}\right\}
$$

ここに,

$\left\{\Delta_{l}\right\}=\left\{\begin{array}{llll}\Delta u_{l} & \Delta w_{l} & \Delta \theta_{l} & \Delta s_{i l}\end{array}\right\}^{T} ;\left\{\Delta_{r}\right\}=\left\{\begin{array}{llll}\Delta u_{r} & \Delta w_{r} & \Delta \theta_{r} & \Delta s_{i r}\end{array}\right\}^{T}$ $\left\{\Delta_{p}\right\}=\left\{\Delta u_{p} \Delta w_{p} \Delta \theta_{p} \Delta s_{i p}\right\}^{T},\left\{\Delta_{p}^{\prime}\right\}=\left\{\Delta u_{p}^{\prime} \Delta w_{p}^{\prime} \Delta \theta_{p}^{\prime} \Delta s_{i p}\right\}^{T}$ $\left[T_{p_{l}}\right]=\left[\begin{array}{cccc}-1 & 0 & 0 & 0 \\ 0 & \frac{p-q-1}{q+1} & 0 & 0 \\ 0 & 0 & -1 & 0 \\ 0 & 0 & 0 & 0\end{array}\right],\left[T_{p_{r}}\right]=\left[\begin{array}{cccc}0 & 0 & 0 & 0 \\ 0 & -\frac{p}{q+1} & 0 & 0 \\ 0 & 0 & 0 & 0 \\ 0 & 0 & 0 & 0\end{array}\right]$

(29) 式を簡略化して再表示すると次式のようになる。

$\left\{\delta_{j s}^{\prime}\right\}=\left[T_{j s}\right]\left\{\delta_{j s}\right\}$

この式の $\left\{\delta_{j s}^{\prime}\right\}$ は変位変換後の内部節点を付加した接合部要素の節 点変位ベクトル増分を表し, $\left[T_{j s}\right]$ は接合部内部のせん断変形を表 現するために設定した変位変換マトリクスである。

(2) 内部節点を含む接合部要素の有限要素方程式

接合部内部の鉄筋の変形は, 接合部内部のコンクリート断面から の相対変位で表されるすべり変位のみを用いて表すことができる。 即ち, 接合部内部の鉄筋層 $i$ の歪增分 $\Delta \varepsilon_{j s_{i}}$ は次式で表せる。

$\Delta \varepsilon_{j s_{i}}=\Delta \varepsilon_{j s s_{i}}=\frac{d \Delta s_{i}}{d x}$

但し, $\Delta \varepsilon_{j s s_{i}}$ : 接合部内部の鉄筋層 $i$ のすべり率の増分（すべり 変位増分の微分量)

また, 接合部内部の鉄筋層 $i$ のための増分型全ポテンシャル・エ ネルギー汎関数 $\Delta \Pi_{j s}$ は以下のように表すことができる。

$$
\begin{aligned}
\Delta \Pi_{j s}= & \frac{1}{2} \int_{0}^{L^{\prime}}\left\{\sum_{i=1}^{m} A_{s_{i}} E_{s_{i}}\left(\frac{d \Delta s_{i}}{d x}\right)^{2}+\sum_{i=1}^{m} A_{b_{i}} K_{b_{i}} \Delta s_{i}{ }^{2}\right\} d x \\
& -\int_{0}^{L^{\prime}}\left\{\sum_{i=1}^{m} \Delta P_{s_{i}}\left(\frac{d \Delta s_{i}}{d x}\right)\right\} d x
\end{aligned}
$$

但し, $L^{\prime}$ : 接合部梁軸方向の内部節点間の長さ

(32) 式を展開し, 整理することで, 接合部内部節点の鉄筋のすべり 
変位に関する有限要素方程式を導くことができる。ここで得られる 剛性マトリクスおよび節点荷重べクトル増分を (30) 式の $\left\{\delta_{j s}\right\}$ のう ち各節点のすべり変位増分と対応した位置に構成し, 次式で表す。

$$
\left[K_{j s}\right]\left\{\delta_{j s}\right\}=\left\{\delta P_{j s}\right\}
$$

但し， $\left[K_{j s}\right]$ : 内部節点を含む接合部要素（梁軸方向）の剛性マ トリクス, $\left\{\delta P_{j s}\right\}$ : 内部節点を含む接合部要素（梁軸方向） の節点荷重ベクトル増分

(30)，(33）式より，内部節点を含む接合部要素の変位変換後の有限 要素方程式は以下のように表すことができる。

$$
\left(\left[T_{j s}^{-1}\right]\right)^{T}\left[K_{j s}\right]\left[T_{j s}^{-1}\right]\left\{\delta_{j s}^{\prime}\right\}=\left(\left[T_{j s}^{-1}\right]\right)^{T}\left\{\delta P_{j s}\right\}
$$

この式の $\left\{\delta_{j s}^{\prime}\right\}$ のうち，(26) (28) 式と対応した変位增分の值を 0 とする拘束条件を設定することで，せん断変形する接合部内部の鉄 筋の変形を表現することが可能となる。

(3) 内部節点変位の縮約

図 5 の内部節点 $1 \sim q$ における節点変位ベクトル増分を $\left\{\delta_{I}\right\}$, 外 部節点 $l, r$ における節点変位ベクトル増分を $\left\{\delta_{E}\right\}$ とし, 拘束条件 の設定を行った (34) 式を, 内部節点, 外部節点とで分けて表示する と次のようになる。

$\left[\begin{array}{ll}K_{I I} & K_{I E} \\ K_{I E}^{T} & K_{E E}\end{array}\right]\left\{\begin{array}{l}\delta_{I} \\ \delta_{E}\end{array}\right\}=\left\{\begin{array}{l}\delta P_{I} \\ \delta P_{E}\end{array}\right\}$

この式から $\left\{\delta_{I}\right\}$ を消去することにより，次式を得る。

$$
\begin{aligned}
\left(\left[K_{E E}\right]\right. & \left.-\left[K_{I E}^{T}\right]\left[K_{I I}^{-1}\right]\left[K_{I E}\right]\right)\left\{\delta_{E}\right\} \\
& =\left\{\delta P_{E}\right\}-\left\{K_{I E}^{T}\right]\left[K_{I I}^{-1}\right]\left\{\delta P_{I}\right\}
\end{aligned}
$$

この式は, (34) 式を外部節点 $l, r$ のみで表す 1 要素に縮約したもの である。即ち，この式を解くことで $\left\{\delta_{E}\right\}$ を得ることができ，更に， その值を (35) 式に代入して $\left\{\delta_{I}\right\}$ についても導くことが可能である。

従って, 接合部のせん断変形に加えて, 接合部内部の鉄筋の付着 すべり分布を考慮した最終的な RC 接合部要素の有限要素方程式は， (36) 式の縮約表示した剛性マトリクスおよび節点荷重ベクトル増分 のうち, 各節点のすべり変位增分に係る成分を前節 (25) 式の対応す る位置に代入することで得られる。

\section{4. 材料モデル}

\section{1 接合部パネルのせん断応力ーせん断歪関係}

図 6 に，本解析で用いる接合部パネルのせん断応力ーせん断歪関 係を示す。単調載荷経路については，最大せん断応力に至るまでを 図に示すような 3 直線で設定し，それ以降の領域では応力值を一定 に保つものと仮定する。本論文では接合部パネルには一様なせん断 変形を仮定しているため,この経路を構成する各点（図 6 中の $1^{+}$, $\left.2^{+}, 3^{+}\right)$の值については，RC 部材に一様な応力が作用した状態を 対象とした Vecchio 等の修正圧縮場理論 7) を用いた解析プログラム による予備解析を別途行い，得られた曲線を近似して設定する。尚， 予備解析において用いるコンクリート，鉄筋の材料モデルについて は文献 7) と同様とする。

除荷・再載荷経路には，接合部パネルの損傷を最大せん断応力の 低隇等により表現する Lowes 等のモデル 3) を本論文では採用する。 このモデルでは, 点 $Q, R, S$ で表される代表的な除荷・再載荷経路 上の各点の値は図中のように設定されており, 応力復䏒点 $S$ のせん 断応力 $\tau_{s}$, せん断歪 $\gamma_{s}$ は次式で表される。

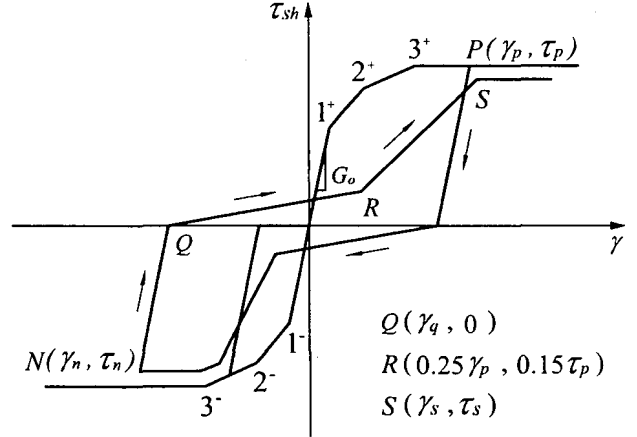

図 6 接合部パネルのせん断応力ーせん断䄳関係

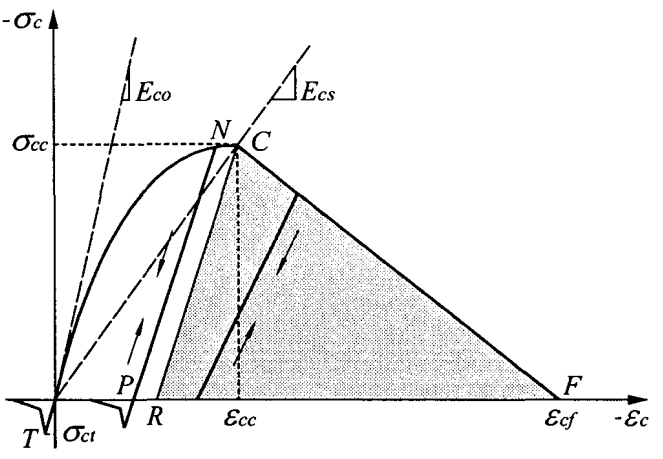

図7 コンクリートの応力ー歪関係

$$
\begin{aligned}
\tau_{s} & =\left(1-d_{t}\right) \tau_{p}=\left\{1-1.11\left(g_{m}\right)^{0.32}\right\} \tau_{p} \\
\gamma_{s} & =\left(1+d_{g}\right) \gamma_{p}=\left\{1+0.12\left(g_{m}\right)^{0.23}\right\} \gamma_{p}
\end{aligned}
$$

但し, $d_{t}$ : 最大せん断応力の低減を表す係数で, $d_{t} \leq 0.125, d_{g}$ : 再載荷時剛性の低減を表す係数で, $d_{g} \leq 0.95, g_{m}$ : 接合 部パネルの損傷度合を表し, $\left|\frac{\gamma_{p}}{\gamma_{3}}\right|,\left|\frac{\gamma_{n}}{\gamma_{3}}\right|$ のうち最大值 尚，本解析では除荷時 $(N \rightarrow Q)$ 剛性に初期剛性 $G_{0}$ を設定する。 4.2 コンクリートの忍一歪関係

図 7 は, 本解析で用いる著者等既往のコンクリートの応力ー歪関 係 ${ }^{6)}$ を示したものである。単調載荷時については, 引張側では, 引 張強度 $\sigma_{c t}$ に達するまでは線形弾性が成立し, その後の経路には応 力を二段階に低減させる $1 / 4$ モデルを採用する。圧縮側においては， 圧縮強度 $\sigma_{c c}$ に到達するまでは次式で表される Saenz 式を用い，圧 縮強度以降は直線的に応力派減する経路を設定する。

$$
\sigma_{c}=\frac{E_{c o} \varepsilon_{c}}{1+\left(\frac{E_{c o}}{E_{c s}}-2\right)\left(\frac{\varepsilon_{c}}{\varepsilon_{c c}}\right)+\left(\frac{\varepsilon_{c}}{\varepsilon_{c c}}\right)^{2}}
$$

但し, $E_{c o}$ : 初期接線係数, $E_{c s}$ : 圧縮強度時の割線係数, $\varepsilon_{c c}$ : 圧縮強度時の歪

本解析では，実験データが与えられている場合を除き， $E_{c o} に は E_{c s}$ の 2 倍の值， $\varepsilon_{c c}$ には $0.2 \%$ の値を仮定する。また, 圧縮終局歪 $\varepsilon_{c f}$ の値は, 要素寸法の依存性を解消するために, 図中の灰色部分の面 積に破壊エネルギーの概念を導入し，次式を用いて設定する。

$$
\varepsilon_{c f}=\frac{2 G_{f_{c}}}{\sigma_{c c} L}+\varepsilon_{c r}
$$

但し， $G_{f_{c}}$ : 圧縮破壊エネルギ一の值を表し， $G_{f_{c}}=8.8 \sqrt{-\sigma_{c c}}$ ， $L$ : 要素長さ, $\varepsilon_{c r}$ : 圧縮強度点 $C$ からの除荷時の残留歪

\section{3 鉄筋の応力ー歪関係}

図 8 に本解析で用いる鉄筋の応力ー歪関係を示す。単調載荷時の 経路については bi-linear 型の応力ー歪関係を設定し, 降伏強度 $\sigma_{s y}$ 
以降の接線剛性 $E_{s 2}$ を初期弾性係数 $E_{s}$ の $1 / 100$ と仮定する。ま た，図に示すように，繰り返し載荷経路に関しては鉄筋降伏後に生じ る Bauschinger 効果をより実現象に近い形で表現し得る MenegottoPinto モデル 8) を採用する。ここで, 載荷反転点 $P$ より始まる履 歴曲線は次式により与えられる。

$$
\begin{aligned}
& \sigma^{*}=R_{s} \varepsilon^{*}+\frac{\left(1-R_{s}\right) \varepsilon^{*}}{\left(1+\varepsilon^{*} R_{b}\right)^{\frac{1}{R_{b}}}} \\
& \text { ここに, } \sigma^{*}=\frac{\sigma_{s}-\sigma_{p}}{\sigma_{o}-\sigma_{p}}, \varepsilon^{*}=\frac{\varepsilon_{s}-\varepsilon_{p}}{\varepsilon_{o}-\varepsilon_{p}}, R_{s}=\frac{E_{s 2}}{E_{s}}
\end{aligned}
$$

但し, $R_{s}$ : 歪硬化係数, $E_{s}$ : 鉄筋の初期弾性係数, $E_{s 2}$ : 鉄筋降伏 後の接線剛性, $R_{b}$ : Bauschinger 効果を表す係数, $\sigma_{p}, \varepsilon_{p}$ : それぞれ載荷反転点 $P$ における応力と歪, $\sigma_{o}, \varepsilon_{o}:$ それ ぞれ履歴曲線の載荷反転点での接線と漸近線との交点 $O$ における応力と䄳

4.4 鉄筋の付着応カーすべり変位関係

図 9 は RC 梁・柱要素および $\mathrm{RC}$ 接合部要素に適用した鉄筋の付 着応力ーすべり変位関係を示したものである。単調載荷時について は図中の点 1〜 5 を通る経路を設定し，各点の值を付着強度点 $\tau_{3}$ を 基準として決定する。繰り返し載荷経路については，図中に示すよ うな森田等の研究 9) に基づいてモデル化した経路を用いる。また， 鉄筋の付着強度は鉄筋に関わる種々の影響要因により変化すること が予想されるため, 本論文では $\tau_{3}$ の值を算定するにあたり，各種要 因による付着強度の増減を表現可能な Lowes 等が提案する付着強度 式 10) を採用する。本解析では，この提案式を基にして増減した付 着強度 $\tau_{3}$ 及びその時点でのすべり量 $s_{3}$ を以下の式 ${ }^{5)}$ で設定する。

$$
\begin{aligned}
& \tau_{3}=\alpha_{1} \cdot \alpha_{2} \cdot \alpha_{3} \cdot \alpha_{4} \cdot \alpha_{5} \cdot \tau_{3}{ }^{\prime}\left[\mathrm{N} / \mathrm{mm}^{2}\right] \\
& s_{3}=\tau_{3} / 20.0[\mathrm{~mm}] \\
& \text { ここに, } \tau_{3}{ }^{\prime}=1.05 \sqrt{f_{c}}
\end{aligned}
$$

但し， $\alpha_{1 \sim 5}$ : それぞれ, 鉄筋周囲のコンクリート応力状態 $\left(\alpha_{1}\right)$, 鉄筋の歪状態 $\left(\alpha_{2}\right)$, 鉄筋のすべり状態 $\left(\alpha_{3}\right)$, 鉄筋径 $\left(\alpha_{4}\right)$, コンクリートかぶり厚さ $\left(\alpha_{5}\right)$ が鉄筋の付着強度に及ぼす 影響を表す係数, $f_{c}$ : コンクリートの圧縮強度

\section{5. 数值計算例}

5.1 姜・北山等の柱梁接合部試験体の実験結果 11$), 12)$ との比較

本解析法の妥当性を検証するため, 姜・北山等の行った柱梁接合 部実験のうち，梁通し主筋の付着性状についての詳細な検討が行わ れた, 形状の異なる 3 体の試験体（試験体 L1，M1，J1）を取り上 げ，数值計算を行ってみることにする。図 10 に解析対象とする各 試験体の要素分割，材料性状を，図 11 に修正圧縮場理論を用いた 予備解析から得た，各試験体の接合部パネルのせん断応力ーせん断 歪関係における単調載荷経路を示す。試験体 L1，M1 は柱梁接合部 を 2 つ有するサ型骨組試験体であり，L1 は中央梁の内法スパンが $2450 \mathrm{~mm}, \mathrm{M} 1$ は内法スパンが $1450 \mathrm{~mm}$ と中央梁のスパン長さが異 なっている。そのため, 接合部内部, 梁端部での主筋の付着劣化の 進展や接合部の変形挙動について, 異なる結果が予想される試験体 である。試験体 J1 は M1 の中央梁中心部分から切出した形状の十字 型骨組試験体であり，M1 との比較用試験体である。各試験体の支持 条件は柱脚がピン支持, 梁端部がピンローラー支持で，柱頭部分で の正負交番繰り返し載荷を層間変形角 $1 / 400$ で 1 サイクル, $1 / 200$,

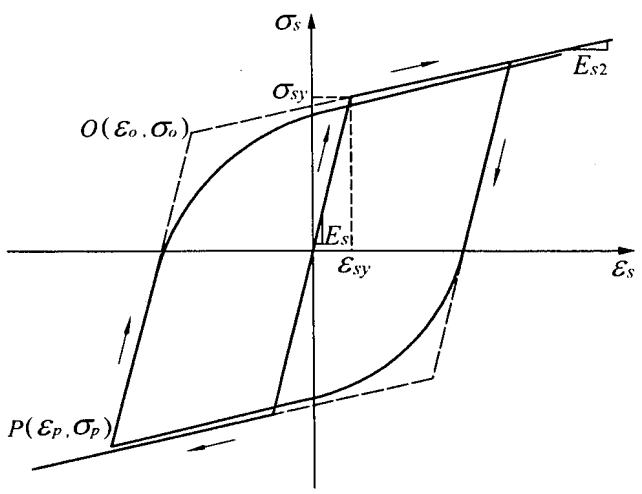

図8 鉄筋の応力ー歪関係

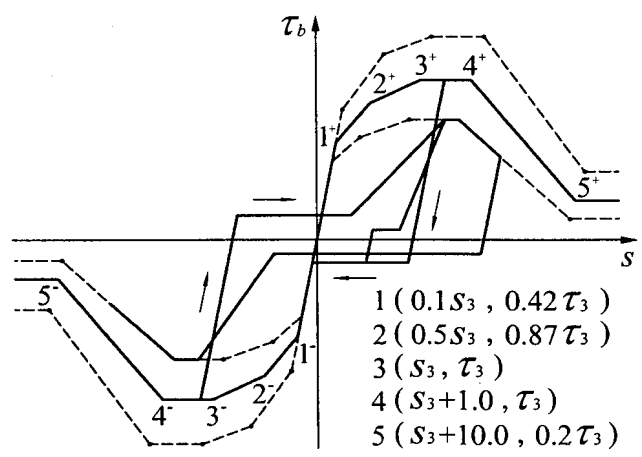

図 9 鉄筋の付着応力ーすべり変位関係

$1 / 100,1 / 50,1 / 25$ で各 2 サイクルを変位制御により行われている。 また，いずれの試験体も柱軸力については加えられていない。

解析は変位増分法を用いて行った。解析にあたり, 梁と柱の要素 長さは $100 \mathrm{~mm}$ を基本として, L1 では左右梁部材を 12 要素, 中央 梁部材を 24 要素, 柱部材を 7 要素に要素分割し, M1，J1 では左右 梁部材, 柱部材を 7 要素, M1 の中央梁を 14 要素に要素分割した。 接合部内部節点数はいずれの試験体についても 3 点を設定した。

図 12 は各試験体の層せん断力ー層間変形角関係における実験結 果と解析結果の比較を示したもので，図の (a) は実験結果，(b) は 接合部パネルのせん断変形を考慮した本解析值, (c) は接合部パネル のせん断変形を考慮しない剛体の接合部要素を用いた場合の解析值 6)についてそれぞれ表示しており，L1，M1については左柱の結果 を表している。まず，(a)，(b)について比較してみると，いずれの 試験体においても本解析值は初期剛性，除荷剛性を若干過大に評価 しているものの, 実験結果に見られるスケルトンカーブや履歴ルー プ形状を概ね良好に追跡可能であることが分かる。また，特に中央 梁スパン長さが最も長い試験体 L1 の本解析值は, 実験結果と同様 に他の 2 体に比べて, 再載荷曲線部分がより緩やかな $\mathrm{S}$ 字形状を呈 しており，試験体の形状の違いが荷重一変形関係に与える影響が表 れている。続いて，(c)についても見てみると，剛体を設定した接合 部要素を用いた解析值は, 梁降伏した層間変形角 $1 / 100$ までは, 本 解析值とほぼ同様な傾向を示しており, 実験結果とも比較的対応す る結果が得られている。しかし, それ以降の変形領域では履歴面積 の大きな紡鍾型の曲線形状を表し, 梁降伏後の剛性, 耐力について も過大に評価する等，実験曲線を捉えきれていない。

次に, 図 13 に本解析值で得られた接合部パネルのせん断応力ー せん断歪関係を示す。図中の值は各層間変形角を表している。図よ り，試験体 M1，J1 の傾向はほぼ同様で，より梁曲げ降伏型と予想 
される L1に比べて接合部のせん断歪量が増加していることが読み 取れる。特に梁曲げ降伏した層間変形角 $1 / 100$ 以降でその差が顕著 となっているが，これは先述の図 12(b) における履歴形状の違いが 表れることに対応する。また，姜・北山等によると接合部パネル部 分の変形割合は $\mathrm{J} 1$ に比べ $\mathrm{M} 1$ の方が増加したという結果が示され ているが,これは, J1 の実験では梁のせん断ひび割れが載荷ととも に増加し, 梁のせん断変形が卓越したことに起因するものと推察さ れ, 梁の変形に曲げと軸方向変形のみを仮定している本解析值では, この現象は表れていない。また，層間変形角 $1 / 25$ では，特に M1， $\mathrm{J} 1$ において接合部せん断歪を $4 \%$ 程度で評価しており, 梁の変形 が主であった実験結果とは定性的に一致しないが，これは接合部パ ネルのせん断応力ーせん断歪関係において, 最大せん断応力以降の 応力值一定の経路において解の収束性が悪くなったことに起因する ものと考えられる。しかしながら, 本解析值は層間変形角 $1 / 50$ ま では, 各試験体とも接合部せん断歪の值は $1 \%$ 程度に収まっており, 実験結果とも対応しているものと思われる。

図 14, 図 15 は試験体 L1, M1 の梁上端主筋の歪分布について負 方向載荷時の各層間変形角における推移を, 実験結果と本解析値で それぞれ示したものであり, 本解析值では 1 サイクル目の結果であ る。実験結果, 本解析值ともに L1, M1 は層間変形角 $1 / 100$ におい て梁端部の引張側主筋が降伏しているが, 本解析值ではこの部分の 歪值を過大に評価する結果となっている。また，M1の実験結果にお いて層間変形角 $1 / 400$ の段階から, 中央梁での梁のせん断ひび割れ に起因した歪零点の左方向へのシフトが見られるが，本解析值では 中央梁ほぼ中心位置で圧縮側から引張側へと歪が転じている。しか し，これらの相違点を除けば，本解析值は L1，M1 ともに実験結果 の歪分布を概ね捉えており，特に接合部内部の主筋の付着すべり分 布を考慮したことで，接合部内部の歪分布を良好に再現する等，本
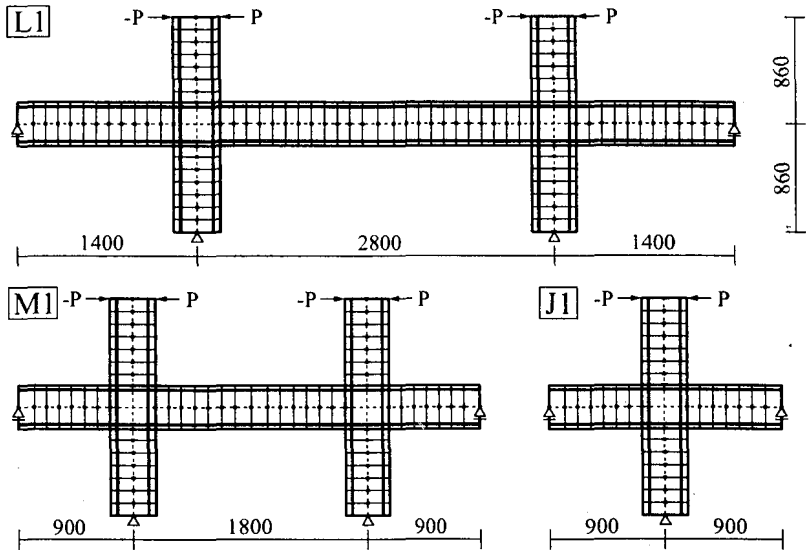

コンクリート $(\mathrm{L} 1, \mathrm{~J} 1) \quad$ コンクリート $(\mathrm{M} 1)$

$E_{c o}=34104 \mathrm{~N} / \mathrm{mm}^{2}, E_{c o}=34104 \mathrm{~N} / \mathrm{mm}^{2}$ $\sigma_{c c}=-42.7 \mathrm{~N} / \mathrm{mm}^{2} \quad \sigma_{c c}=-44.5 \mathrm{~N} / \mathrm{mm}^{2}$ $\sigma_{c t}=3.22 \mathrm{~N} / \mathrm{mm}^{2} \quad \sigma_{c t}=3.35 \mathrm{~N} / \mathrm{mm}^{2}$ $\varepsilon_{c c}=-0.25 \%$

梁主筋 D-16 $\varepsilon_{c c}=-0.26 \%$

$E s=188302 \mathrm{~N} / \mathrm{mm}^{2} \quad E s=192774 \mathrm{~N} / \mathrm{mm}^{2}$ $E s 2=1883.0 \mathrm{~N} / \mathrm{mm}^{2} E s 2=1927.7 \mathrm{~N} / \mathrm{mm}^{2}$ $\sigma_{s y}=346.1 \mathrm{~N} / \mathrm{mm}^{2} \quad \sigma_{s y}=363.2 \mathrm{~N} / \mathrm{mm}^{2}$ $\varepsilon_{s y}=0.1838 \% \quad \varepsilon_{s y}=0.1884 \%$

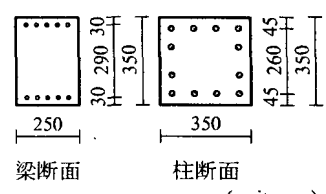
(unit:mm)

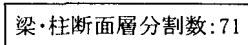
接合部内部節点数: 3

図 10 姜・北山等の柱梁接合部試験体の概要
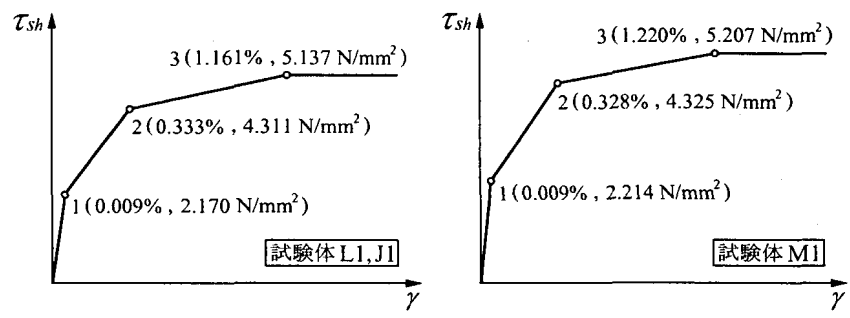

図 11 仮定接合部パネルせん断応力ーせん断歪関係
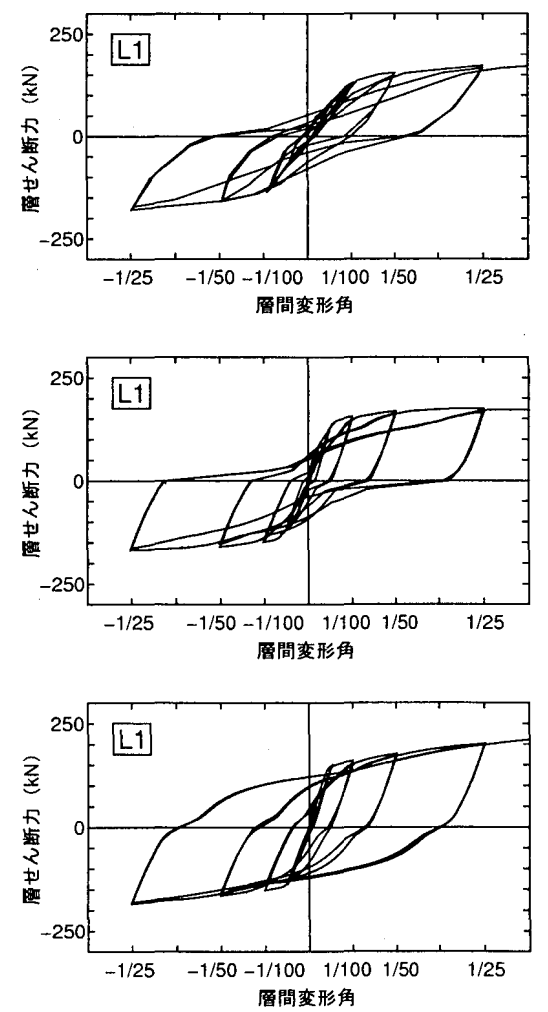

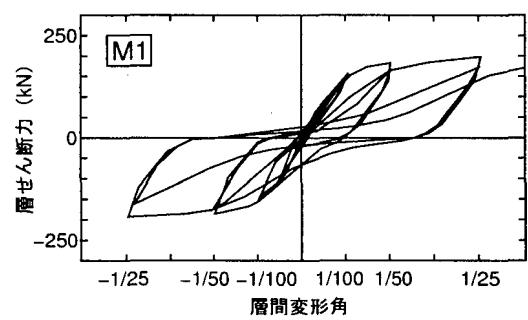

(a) 実験結果

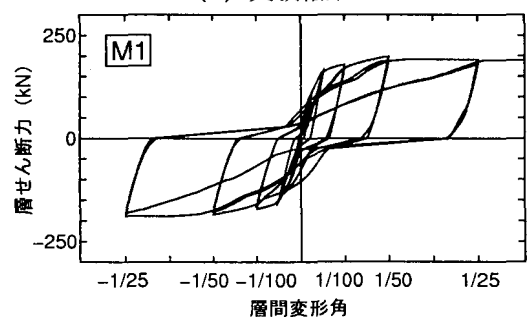

(b) 本解析値

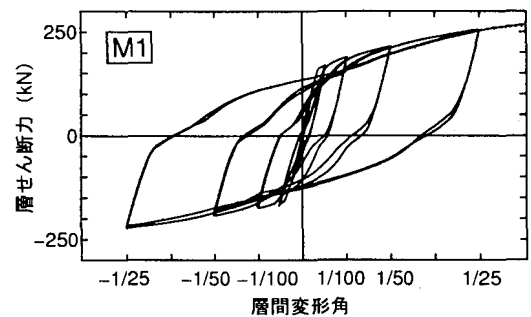

(c) せん断変形無視の剛体接合部要素を用いた解析値 ${ }^{6)}$

図 12 各試験体における層せん断力ー層間変形角関係の比較
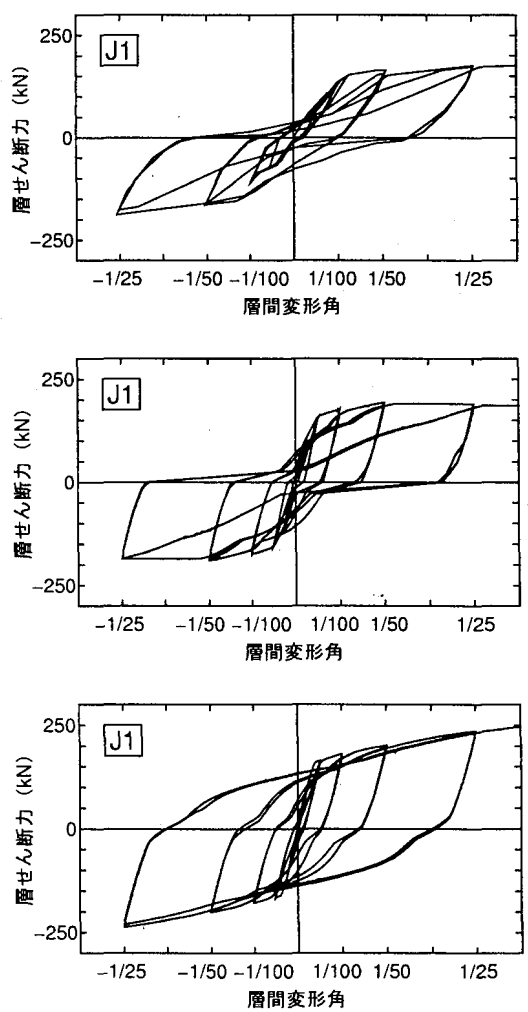

層間変形角 

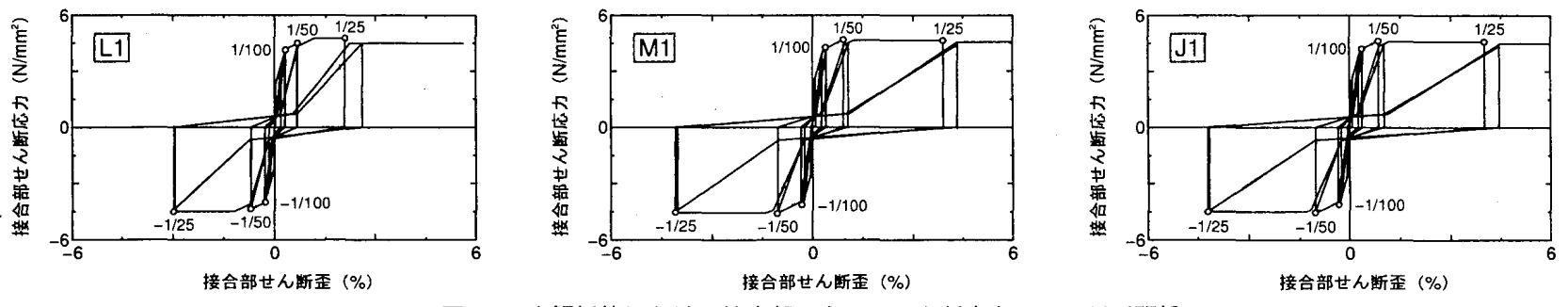

図 13 本解析值における接合部パネルのせん断応力ーせん断歪関係

解析法が RC 骨組全体の主筋の歪性状についても概效表現可能なこ とが分かる。

図 16 は試験体 $\mathrm{M} 1, \mathrm{~J} 1$ の接合部中央位置での梁上端主筋すべり 量を実験結果と解析結果で比較したもので，M1については右側接 合部の結果を表したものである。本解析值は層間変形角 $1 / 25$ です ベり量をやや過小評価しているものの，全体的には実駼結果と良好 に対応した結果が得られている。これに対して，接合部を剛体と仮 定した解析值 6)では載荷初期段階からすべり量を過大評価してお り, 特に J1 ではその增加傾向が顕著で, 実験結果を全く表現してい ない。この解析結果の相違は，接合部パネルのせん断変形を考慮し たことで, 梁曲げヒンジ領域における曲げ変形量が全般的に減少す る傾向が見られ，この結果として主筋の抜け出しをより実現象に近 い形で評価したことによるものと推察され，本解析法が主筋のすべ り量についても, 比較的精度良く追跡し得ることを示唆している。

\section{6. まとめ}

本論文では, 接合部のせん断変形および接合部内部の主筋の付着 すべり分布を考慮した RC 骨組の材料非線形解析法について論じ た。即ち, 骨組解析の基本となる $\mathrm{RC}$ 梁・柱要素の概要と新たに提 案したせん断変形を表現し得る $\mathrm{RC}$ 接合部要素について示し，次い で解析に採用した各材料モデルについて記述した。更に，数値計算 例として, 形状の異なる 3 体の既往の実験結果を取り上げ, 解析結 果との比較・検証を行った結果，以下のような知見を得た。

(1)接合部パネルのせん断変形を考慮した本解析法は, 十字型, サ型 等の内柱接合部を含む $\mathrm{RC}$ 骨組を対象とした場合に，実駼結果の 荷重一変形曲線を概ね良好に追跡可能である。

(2)せん断変形する接合部内部の主筋の付着すべり分布を考慮した本 解析法は，実験結果に見られる主筋の歪性状，すべり量を概ね良 好に評価しており，剛体接合部要素を用いた解析值に比べ，より 実験結果と対応した結果を得た。

\section{参考文献}

1）鉄筋コンクリート造建物の勒性保証型耐震設計指針・同解説，日本建築学 会, pp.241-277, 1999

2) 坂田弘安, 和田章, 林静雄, 黒正清治 : 接合部パネルのせん断変形, 鉄筋 の付着すべりを考慮した分割要素法による鉄筋コンクリート骨組の弾塑性 解析法, 日本建築学会構造系論文報告集, 第 386 号, pp.24-34, 1988.4

3) Laura N. Lowes, Arash Altoontash : Modeling Reinforced-Concrete Beam-Column Joints Subjected to Cyclic Loading, Journal of Structural Engineering, pp.1686-1697, 2003.12

4) 齊藤隆典, 越川武晃, 上田正生, 菊地優 : 柱梁接合部における主筋の付着 すべりを考慮した RC 平面骨組の履歴挙動解析，コンクリートエ学年次論 文集, Vol.27, No.2, pp.73-78, 2005

5) 齊藤隆典, 越川武晃, 上田正生, 菊地優 : 主筋の付着特性に影響を及ぼす 各種要因を考虑した RC 骨組の履歴挙動解析, 構造工学論文集, Vol.52B, pp.101-108, 2006.3

6) 齊藤隆典, 越川武晃, 上田正生, 菊地優 : 柱梁接合部内主筋の付着すべり 分布を考慮した RC 骨組の履歴挙動解析，コンクリート工学年次論文集，

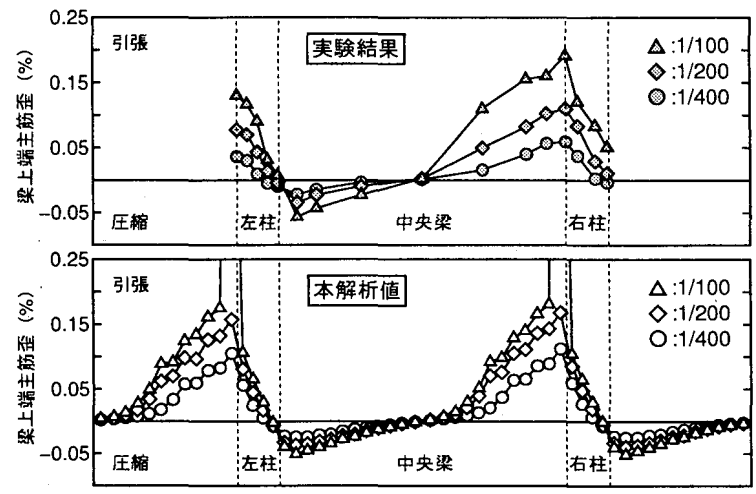

図 14 試験体 L1 の梁上端主筋歪分布の比較
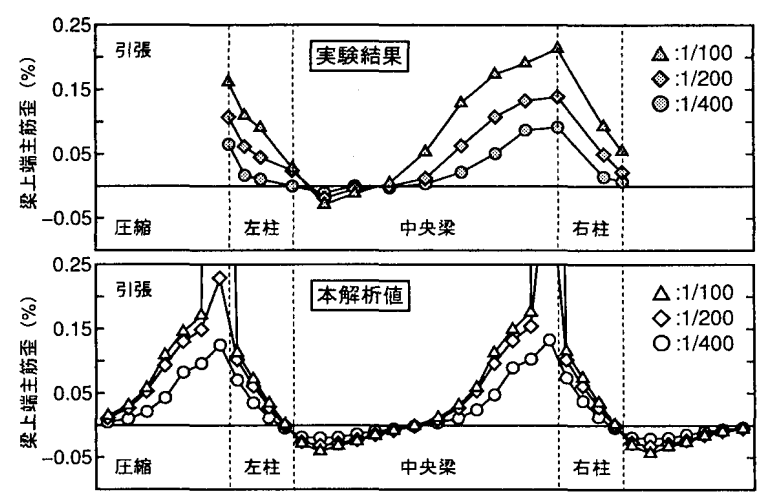

図 15 試験体 M1 の梁上端主筋歪分布の比較

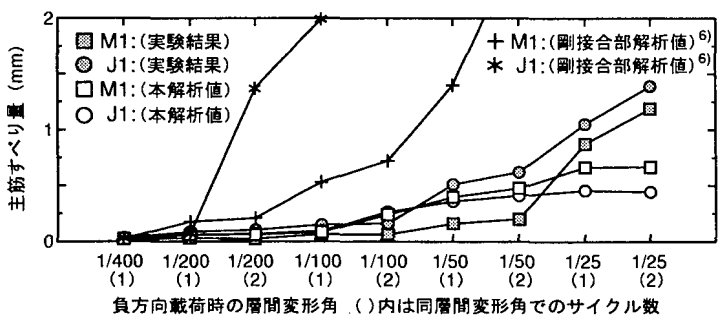

図 16 接合部中央位置の梁上端主筋すべり量の比較

Vol.28, No.2, pp.85-90, 2006

7) Frank J. Vecchio, Michael P. Collins : The Modified Compression Field Theory for Reinforced Concrete Elements Subjected to Shear, ACI Journal, Vol.83, No.2, pp.219-231, 1986.3-4

8) 堺淳一，川島一彦:部分的な除荷・再載荷を含む履歴を表す修正 MenegottoPinto モデルの提案, 土木学会論文集, No.738, I-64, pp.159-169, 2003.7

9) 森田司郎，角徹三:繰り返し荷重下における鉄筋とコンクリート間の付着 特性に関する研究, 日本建築学会論文報告集, 第 229 号, pp.15-24, 1975.3

10) Laura N. Lowes, Jack P. Moehle, Sanjay Govindjee:Concrete-Steel Bond Model for Use in Finite Element Modering of Reinforced Concrete Structures, ACI Structural Journal, Vol.101, No.4, pp.501$511,2004.7-8$

11）姜柱, 北山和宏 : RC 骨組内の柱・梁接合部の入力せん断力と梁通し筋の 付着に関する研究，構造工学論文集，Vol.42B，pp169-179，1996.3

12）姜柱, 北山和宏, 香山恆毅, 吉田智基: 鉄筋コンクリート骨組内の梁通し 筋の付着特性に関する研究，コンクリート工学年次論文報告集，Vol.17， No.2, pp297-302, 1995 